\title{
Assessment of Perceived Health And Environmental Problems of Household ENERGY CONSUMPTION AMONG ILESE IJEBU RESIDENTS SOUTHWESTERN NiGERIA
}

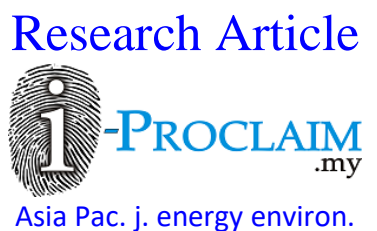

\section{Adegbite A. Ayoade ${ }^{1 *}$, Sikiru G Salako², A. M Yusuf-Babatunde ${ }^{3}$, Olubanji A Lawal ${ }^{4}$, M Adeoye KuKu}

\author{
${ }_{1,4}^{1,4}$ Department of Water Resources Management and Sanitation, Ogun State College of Health Technology, Ilese-Ijebu, P.M.B 2081, Ijebu Ode, NIGERIA \\ ${ }^{2}$ Department of Environmental Health Technology, Ogun State College of Health Technology, Ilese-Ijebu, P.M.B 2081, Ijebu Ode, NIGERIA \\ ${ }^{3}$ Department of Pharmaceutical Technology, Ogun State College of Health Technology, Ilese-Ijebu, P.M.B 2081, Ijebu Ode, NIGERIA \\ ${ }^{5}$ Department of Health Promotion and Education, Ogun State College of Health Technology, Ilese-Ijebu, P.M.B 2081, Ijebu Ode, NIGERIA
}

*Email for Correspondence: aagbite@ yahoo.co.uk

The study was carried out among Ilese-Ijebu residents southwestern Nigeria, to assess their perceived health and environmental problems associated with different sources of household energy use for cooking, then their perception and acceptability of adopting other alternative source of energy (biogas). A focused group discussion and self-structured questionnaire administration methodologies were adopted to elicit information on their current energy sources and adoption for alternative energy source (biogas). The researchers randomly selected twenty five (25) households to include the total sample size of one hundred (100) and organized an interactive session on the subject matter, during which three prepared forms were given out to the participants to filled their demographics characteristics, sources of energy for household cooking with associated health and environmental problems and perception and acceptability of biogas, descriptive statistics and likert scale technique were used to analyze the results obtained. The results of the analysis showed that, the respondents do make use of more than one source of energy for cooking, kerosene stoves (95), firewood (63), charcoal stove(32), while lesser people made use of liquefied gas (12) and electricity (5). Average numbers of respondents 50-60 are aware of associated health and environmental problems with firewood and charcoal, but not ready to use electricity and liquefied gas because of bills and fire hazards when the energy sources is not properly handled. However, the likert scale results of the positive score of 227 and the negative score of 598 on the acceptability of use of biogas for domestic cooking indicating that, presently, the residents are not ready to adopt the biogas as the alternative energy. Therefore, there is need to organize massive awareness campaign, health education talks among the residents on the effect of air pollution associated with household energy sources and consumption, health and financial benefits of adopting other alternative clean energy source.

Key words

Perceived Health Problem, Environment, Household Energy, Biogas Liquefied gas

This article is is licensed under a Creative Commons Attribution-NonCommercial 4.0 International License.

Attribution-NonCommercial (CC BY-NC) license lets others remix, tweak, and build upon work non-commercially, and although the new works must also

acknowledge \& be non-commercial.

\section{INTRODUCTION}

According to World Health Organization report (2006), worldwide, more than three billion people depend on solid fuels, including biomass wood, dung and agricultural residues) and coal, to meet their most basic energy needs: cooking, boiling water and heating (WHO, 2006). These sources of household energy produces thick grey smoke that fills the air, making breathing unbearable and bringing tears to the eyes (WHO, 2006). Furthermore, the inefficient burning of solid fuels on an open fire or traditional stove indoors creates a dangerous cocktail of hundreds of pollutants, primarily carbon monoxide and small particles, but also nitrogen oxides, benzene, butadiene, formaldehyde, polyaromatic hydrocarbons and many other health-damaging chemicals. The daily exposure among the residents to indoor air pollution, especially the women and children is very high, where the residents breathe in various pollutants/contaminants. Also, places where coal is used, releases of sulphur, 
arsenics and fluorine might occur, thereby resulting to more health and environmental consequences among the people. In addition to the above information, About 2.5 billion people in developing nations depend on biomass fuels for household cooking and lighting (Oparinde, 2010)

Though, there are various researches and studies on indoor pollution associated with household energy consumption that have great negative impacts on both human and environment for instance, the black lung disease that occurred among Native American women some years back (Botkin and Keller, 2012). Other problems include, inflammatory of mucous membranes of the nose, nasal congestion, nose bleed, cough, wheezing, worsening asthma, labored breathing, severe lung disease, irritation of mucous membranes of eyes, headache or dizziness, lethargy, fatigue, malaise, nausea, vomiting, anorexia, cognitive impairment, personality change, rashes, fever, chills, abnormal heartbeat, retinal hemorrhage, muscle pain, cramps and hearing loss (Botkin and Keller, 2012). In poor developing-country households, wood, charcoal and other solid fuels (mainly agricultural residues and coal) are often burned in open fires or poorly functioning stoves. Incomplete combustion leads to the release of small particles and other constituents that have been shown to be damaging to human health in the household environment (Smith, 1993).

On the other hand, these sources of energy for household consumption can result to environmental degradation through deforestation for instance, trees are fell for their woods and charcoal for domestic cooking, and the formation acid rain as a result of smokes that contain oxides of carbon and sulphides released into the atmosphere that combine with water molecules and come down as acidic rain, having effect on the roofing of houses and can distort the chemistry of soil. Therefore, the health problems and environmental implications of air pollution require continuous monitoring and attention of people and need for other clean sources of energy for household consumption.

However, the study focused on the household energy consumption for cooking among the Ilese-Ijebu residents with the following objectives:

a. To determine the residents perceived health problems and environmental implications on the energy they used for cooking.

b. To assess the residents perception and acceptability for other sources of energy (Biogas).

\section{Materials AND Methods}

The study was qualitative in nature, where a focused group discussions methodology and a structured questionnaire administration were used. These methodologies are form of research techniques in which a group of people are asked about their opinions, beliefs and attitudes towards a product, service, concept, advertisement, ideas or packaging (Cryer, 2009). The researchers organized an interactive session at twenty five (25) households with the average of four (4) residents- making the total sample size for the study one hundred (100). There was the introduction about the subject matters, and three prepared forms were given out to the participants. The forms contain the following:

The first forms were given out after they have accepted to be part of the discussions, those that cannot read and write the contents of the forms were explained in the local dialect.

(a) The demographics characteristics of the participants that requested for their years of residency at their households, ownership status (Do they own the houses, rent it or otherwise), the occupation, the incomes?)

The second forms were given out after the subject matter were introduced to them

(b) The different sources of energy for household cooking listed with columns for health and environmental problems associated with these energy sources.

Then, the third forms were given out after there were discussions with the residents on the forms they filled and they were able to connect with the health and environmental problems, the researchers have to add with the ones they identified themselves.

(c) Then, forms on alternative source of energy for household cooking specifically biogas were given to the participants for their perception and acceptability using positive and negative statements adopted after (Loiselle, et al; 2004). 


\section{Results AND Discussion}

\section{Results on Demographics Characteristics of the Participants}

The section contained responses on the demographic characteristics of the participants

Table I: Showing the Years of Residency at the Households by the Respondents

\begin{tabular}{|c|c|c|c|c|c|c|c|}
\hline Year & Freq & Ownership & Freq & Occupation & Freq & Income & Freq. \\
\hline $1-15$ & 10 & Landlord & 60 & Housewife & 15 & $<1000$ & 35 \\
\hline $16-30$ & 35 & Rented & 35 & Trading & 76 & $1000-10000$ & 55 \\
\hline$>30$ & 55 & Others & 5 & Artisan & 09 & $>10000$ & 10 \\
\hline Total & $\mathbf{1 0 0}$ & & $\mathbf{1 0 0}$ & & $\mathbf{1 0 0}$ & & $\mathbf{1 0 0}$ \\
\hline
\end{tabular}

Source: Researchers field work 2015

From the responses as shown in table 1, it was shown that ten (10) of the respondents have been living in their apartments between 1-15 years, thirty five (35) have spent between 16-30 years in their apartment/dwellings and the rest respondents more than half, fifty five (55) have being staying for over more than thirty years. The responses on the house ownership showed that, sixty (60) of the respondents owned the houses or inherited from their husbands, while thirty five (35) are tenants and the rest five (5) respondents neither owned the houses or pay rents.

Furthermore, the results also showed that fifteen (15) of the respondents are housewives, seventy six (76) were traders and nine (09) were artisans. Though, the majority of the house owners collect rents from their tenants which also serve as source of income. The table also showed that thirty five (35) of the respondents earn less than one thousand naira ( $\$ 1000)$ in a month, equivalent of \$5.02, fifty five of the respondents earn between $\$ 1000$ - $\$ 100,000$ in a month which is between $\$ 5.02-\$ 199.25$ and rest ten (10) respondents claimed to have income more than 100,000 in a month (income more than $\$ 199.25$ monthly).

\section{Results on the sources of energy used for household cooking}

Table II: Showing Different Sources of Energy Used at the Households.

\begin{tabular}{|l|c|}
\hline Sources of energy & Percentage \\
\hline Kerosene & 95 \\
\hline Firewood & 63 \\
\hline Charcoal & 32 \\
\hline Liquefied Gas & 12 \\
\hline Electricity & 05 \\
\hline All the sources & 20 \\
\hline
\end{tabular}

Source: Researchers field work 2015

The table II above showing the responses on various sources of energy uses by the respondents for cooking. The figures showed that almost all the participants, ninety five (95) out of one hundred (100) do make use of kerosene stoves for cooking, followed by sixty three (63) use firewood for cooking, thirty two (32) uses charcoal stove for cooking. Lesser people made use of liquefied gas (12) and electricity (5). However, twenty (20) of the participants do use all of the energy sources depending on the situations and when conditions warrant it.

Results on the Health Problems and Environmental Implications associated with household energy use for cooking. This section and table III below contained responses of the participants on the questions raised on each sources of energy they uses, whether they are aware of the health problems and environmental implications associated with them.

Table III: Responses on Health problems and Environmental Implications associated with the sources of energy used for cooking.

\begin{tabular}{|l|c|c|}
\hline Energy Sources & Responses on Health Problems & Responses on Environmental Problems \\
\hline Kerosene & 20 & 40 \\
\hline Firewood & 60 & 65 \\
\hline Liquid gas & - & - \\
\hline Electricity & - & - \\
\hline Charcoal & 10 & 10 \\
\hline
\end{tabular}

Source: Researchers field work 2015

The above table shows that the respondents believed that only three out of the sources of energy used which is kerosene, firewood and charcoal can cause health and environmental problems due to the smokes released, from 
which they inhaled and when released to the environments cause poor visibility around the houses. Twenty (20) and forty (40) respondents mentioned kerosene stove to be harmful to health and environment respectively, while sixty (60) and sixty five (65) believed also that firewood energy is very harmful to both human health and to the environment and ten (10) respondents indicated that charcoal usage can be harmful to health and environment.

Table IV: Responses on acceptability/ agreement on the use of biogas as an alternative source of energy consumption.

\begin{tabular}{|l|c|c|c|c|c|c|c|}
\hline & \multirow{2}{*}{ SA } & \multirow{2}{*}{ A } & \multirow{2}{*}{ ? } & \multirow{2}{*}{ D } & SD & \multicolumn{2}{|c|}{ SCORE } \\
\hline & & & & & & + & - \\
\hline 1)Biogas usage do not constitute health risks & 12 & & & & & 60 & \\
\hline 2)Biogas can help to maintain the faecal sludge & & 35 & & & & 140 & \\
\hline 3)Biogas can easily be managed at household level & & & 9 & & & 27 & \\
\hline 4)Biogas cannot be accepted by the community & & & & & 45 & & 225 \\
\hline 5)Biogas cannot be enough for household cooking & & & & 67 & & & 268 \\
\hline 6)Biogas cannot be maintained at household & & & 35 & & & & 105 \\
\hline Total & & & & & & $\mathbf{2 2 7}$ & $\mathbf{5 9 8}$ \\
\hline
\end{tabular}

Source: Researchers field work 2015

The method was adopted from (Loiselle, et al; 2004) *Positive statement**Negative statement, Strongly Agreed (SA), Agreed (A), No idea (?), Disagreed (D), Strongly Disagreed (SD)

Note: After exercises and discussions on the problems associated with using different types of energy for household cooking, the needs of using and adopting of other energy sources were introduced and discussed, the above form of table IV were given to the participants for their agreement and acceptability of Biogas as alternative source of Energy for cooking

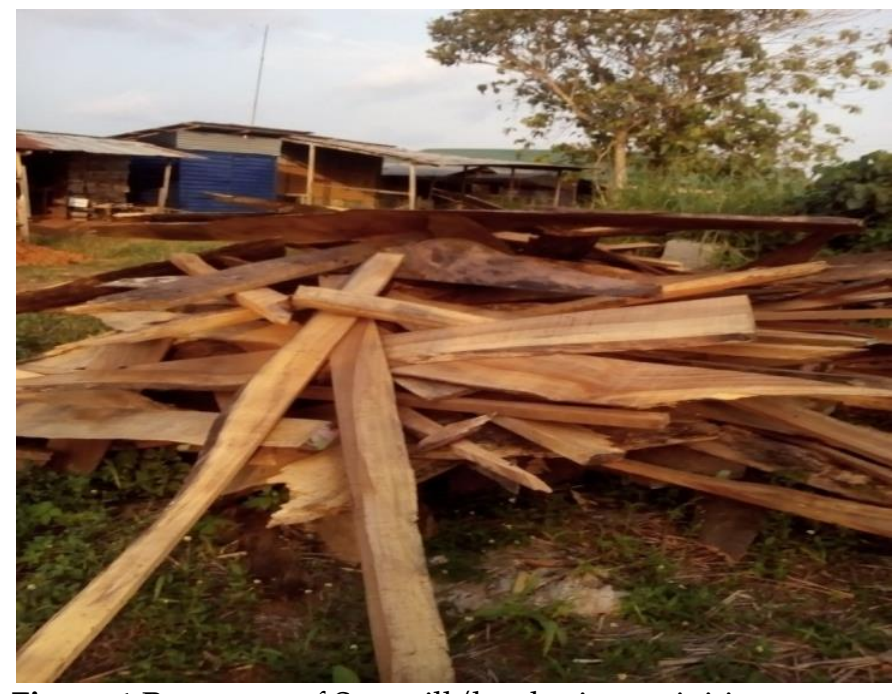

Figure 1:Remnants of Sawmill/lumbering activities

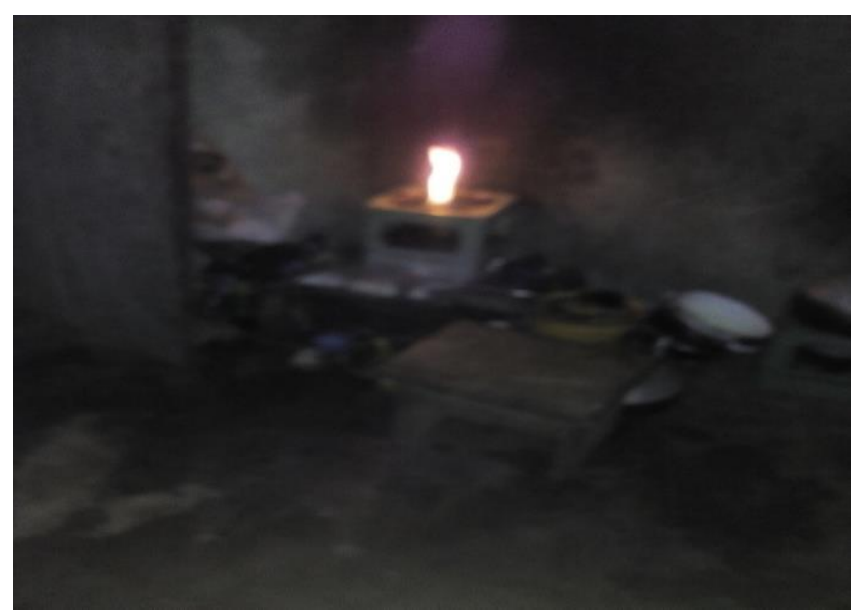

Figure 3: Burning Kerosene Stove

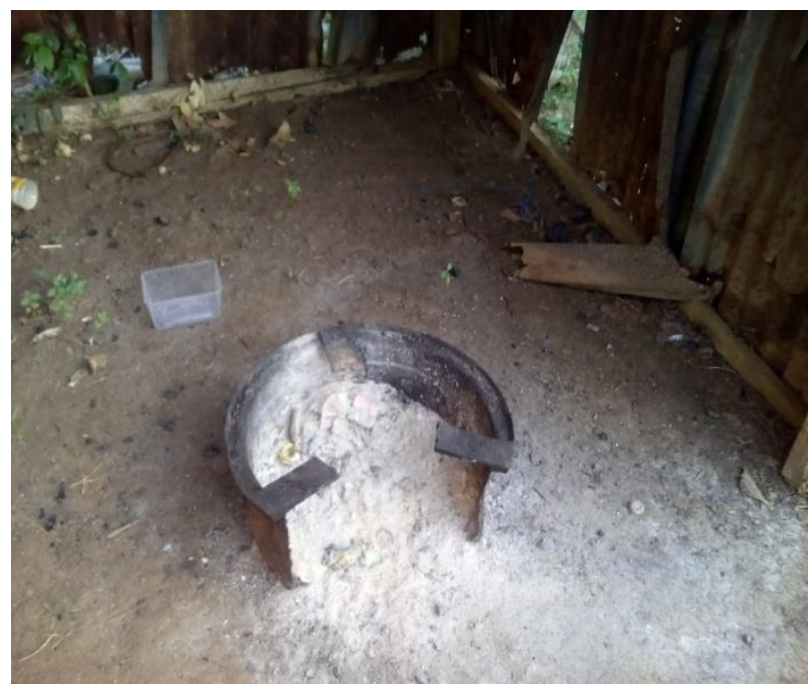

Figure 2: Firewood Stove with a makeshift kitchen

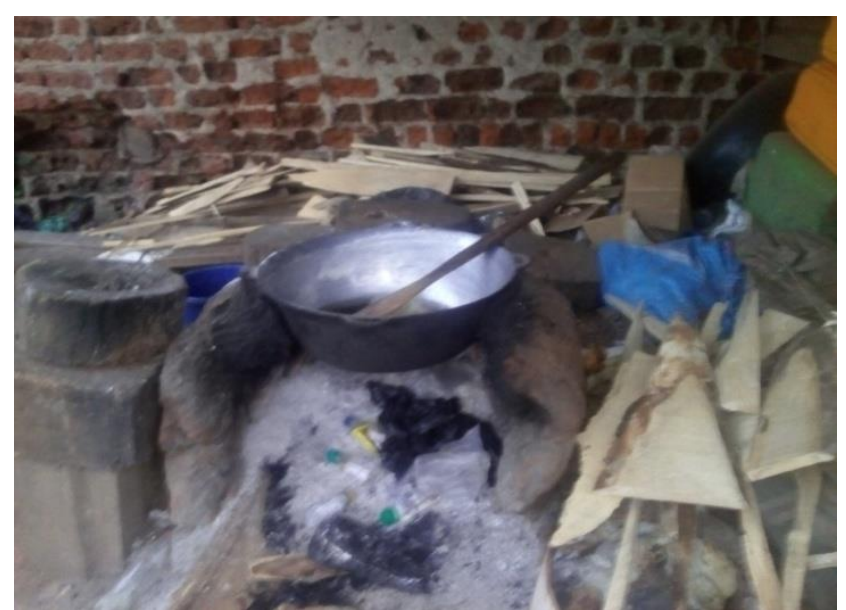

Figure 4: Firewood stove 


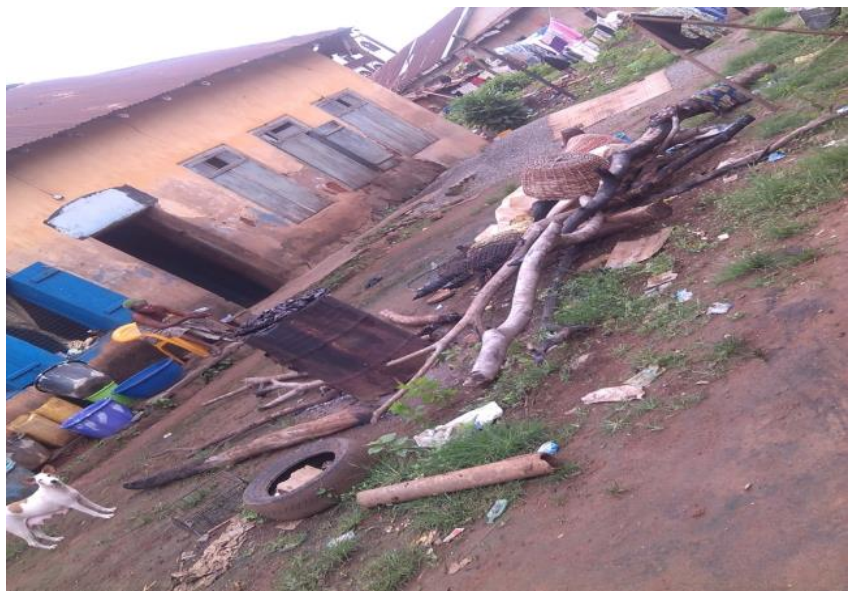

Figure 5: Kiln for Fish Smoking

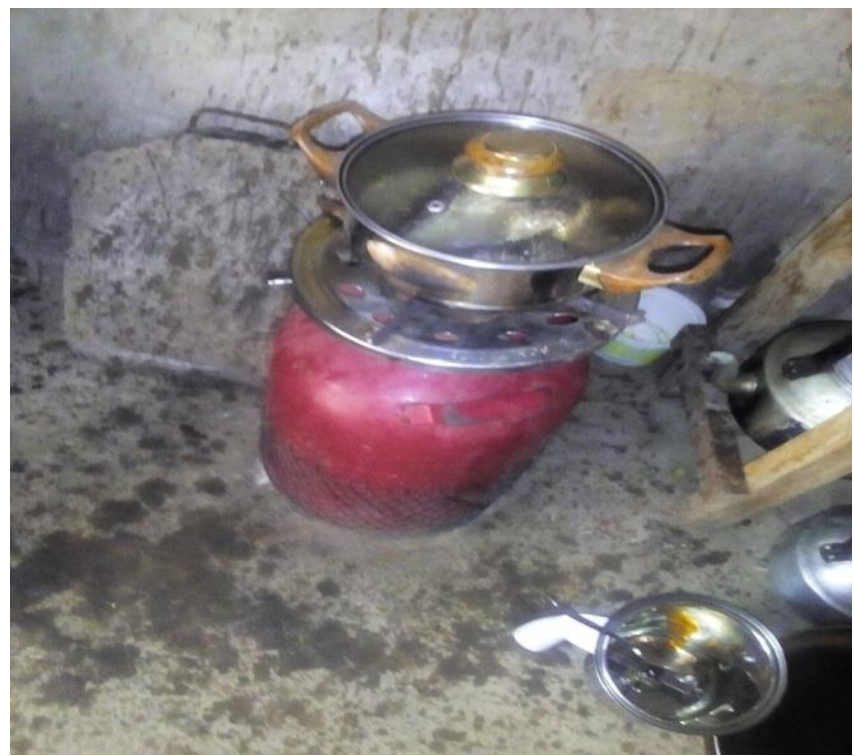

Figure 7: Gas stove/burner

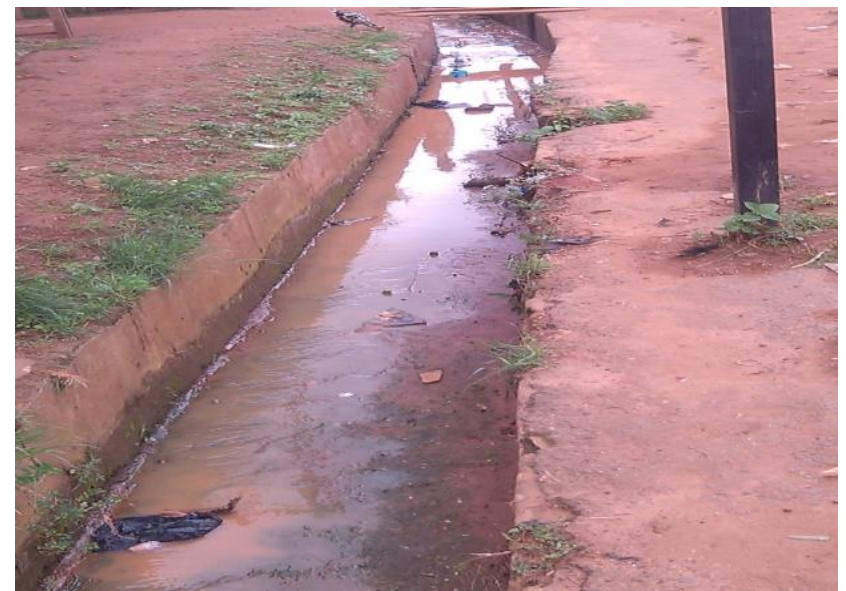

Figure 6: Open Drainage where feaces are dropped

\section{Discussions}

Generally, the energy consumption in the households, have direct implications for the challenging health and environmental issues. Infact, there are factors that are responsible for energy choices and consumption. For instance, poverty level, socio-economic status, attitudes, cultures, housing conditions, and household composition among others determine or relate to household energy choice and consumption (Sjöberg and Engelberg, 2005), (Van Raaij and Verhallen, 1983) Furthermore, from previous studies, for instance, Poortinga, et .al; (2004) in their work, citing other different work believed that environmental attitudes and behavior are related to people's values and the poor knowledge of the people of the study area on global environmental problems are clearly linked to individual behavior on household energy consumption and acceptability of other better and clean sources of energy (Brandon \& Lewis, 1999; Noorman and Schoot Uiterkamp, 1998).

The study revealed that despite health and environmental problems associated with common energy sources like firewood, kerosene stove, charcoal use for domestic cooking, the residents are not ready to adopt other better energy sources that can be less harmful to human health and environmental friendly. Specifically, the study introduced to the residents a biogas, though within any of its drawback, biogas energy for household, has high quality cooking fuel produced for free (saving trees)- reduction of deforestation and reduce emission of gas that deplete ozone layers, therefore, the energy type is hygienic and no utilities required.

Unfortunately, the majority of the respondents do not accept the use of biogas for domestic cooking where the feaces and animal wastes are converted into methane gas for their uses. Table IV showing the positive score (227) is less to negative score (598), an indication that the biogas uses among the respondents, presently cannot be readily acceptedthe results support the report (Hammed, 2015), that Nigeria with her peculiar problems which are socio-cultural, political and financial, it always difficult to introduce new concepts (Hammed, 2015). From point of financial 
implications, the respondents rejection might be in their thinking that they are going to contribute huge finance not be bother of how much they pay for health and medical attentions and Hammed (2015), discussing from the point of environmental implications, further stressed that there no little of no enforcement of laws to prevent surface water and air pollution from the disposal of human excreta in public drains, water bodies, open areas. As a results, statistically, Diarrhoea kills about 194,000 children under five every year and respiratory infections kill another 240,000 (Hammed.2015). Thereby, the incidence and prevalence of death associated with air pollution and water pollution can be reduced when Biogas can used as alternative source for household energy consumption, where there are little dependence of current energy sources among the residents and conversion of toilets waste into energy for aesthetic qualities of the environment and prevention of water resources pollution within the study area and for other various advantages highlighted by (Swami, 2012).

Moreover, the study revealed the residents energy consumption model are relatively followed by the model of (Van Raaij and Verhallen, 1983), which was that Energy-related attitudes are price concern, environmental concern, energy concern, health concern, and attitudes toward personal comfort. For instance, some respondents that are tenants like to use electric cookers, liquefied gas because of health and environmental concerns are always prevented by the landlords and in many cases the 'errant' tenants are ejected because, using the electric cookers and liquefied gas stove (see figure 7 above), the electricity bills would be higher, this responses supported by (Knöpfle, 2004) and they are scared of fire hazards that in many cases fire outbreaks in houses were as results of electric cookers and misuse of liquefied gas mishandling and in other words the house owners are not always comfortable by electricity, liquefied gas energy sources, but comfortable with wood and charcoal energy sources.

Therefore, price concern coupled with low income status of the residents is another issue that influence the residents' household energy consumption, the common energy source kerosene stove solely depend on the availability of the kerosene. Sometimes when there is fuel (kerosene) scarcity with price increased, the majority of the residents resort to firewood and charcoal, though in some reports like Union of Concerned Scientists, authored by Calen May-Tobin (2011) that believed that In most parts of Sub-Saharan Africa, firewood collection and trade is considered sustainable. Most material collected is already dead, and collection rates are typically below the regeneration rate and unlike firewood, charcoal usually comes from trunks or large limbs and requires cutting trees. While charcoal may not always be the primary driver of deforestation, it can contribute significantly to degradation and destruction of forests that have already been disturbed. Unfortunately, on the other hands, the harmful smoke which emanate from the use of charcoal and firewood help in damaging the lungs and cause respiratory diseases and discomfort of eye itching and redness and heat exposure complained by the respondents are of health issues associated with the uses of the firewood and charcoal (State of Victoria, 2015) and (EHHI, 2015).

However, from general discussions with the respondents, they have low perception of household energy fuels as a form of air pollution that require low exposure to and the need for other source for alternative clean energy sources for domestic consumption.

\section{CONCLUSION}

From the analysis of the data and results obtained, the study conclude that the residents still commonly depend and utilize firewood and charcoal energy sources for their household cooking that make them to be exposed to respiratory and skin diseases. Though, on the small and local scale, the household energy consumption contribute to green houses gases. Then, the respondents do not accept the use of biogas as an alternative source of energy for household cooking, this is because of their low level of understanding and believe huge money will involved and cannot relate and link the uses of biogas in helping them to reduce their exposure to air pollution and sustain the groundwater and environmental qualities, prevent human contacts from improper disposal of feacal sludge when the toilets are full. The study recommend that there is need to organize massive awareness campaign, health education talks among the residents on air pollution associated household energy sources, health and financial benefits of adopting other alternative sources of energy, Therefore, there is need for the residents to allow specifics medical check up to determine the impact of the air pollution exposure as a result of sources of household energy used for cooking.

\section{REFERENCES}

Botkin, D. B and Keller, E.A (2012) Environmental Science Earth as a living planet. 2nd edition. Canada: John Willey and Sons.

Cryer, A. B. (2009) Focus group explained. Available at: http:/ / everything.explained.today/Focus_group/ (Accessed: 5 December 2015).

Cunliffe, L. What's driving tropical deforestation to Day? Wood for fuel. Available at: http://www.ucsusa.org/sites/default/files/legacy/assets/documents/global_warming/UCS_Drivers of Deforestation_Chap8_Woodfuel.pdf (Accessed: 5 December 2015).

EHHI Environment and Human Health Inc, (2015): The health effects of wood smoke. Available at: http:/ / www.ehhi.org/woodsmoke/health_effects.shtml (Accessed: 5 December 2015). 
Frederiks, E., Stenner, K. and Hobman, E. (2015) 'The Socio-Demographic and psychological predictors of residential energy consumption: A comprehensive review', Energies, 8(1), pp. 573-609. doi: 10.3390/en8010573.

Gatersleben, B., Steg, L. and Vlek, C. (2002) 'Measurement and determinants of environmentally significant consumer behavior', Environment and Behavior, 34(3), pp. 335-362. doi: 10.1177/0013916502034003004.

Hammed, B. (2015) 'Faecal Sludge Management: Challenges, Opportunities and Public Health Implications', Paper Delivered at World Toilet Day Organised by Department of Water Resources Management and Sanitation, Ogun State College of Health Technology, Ilese-Ijebu: unpublished. .

Knöpfle, M. (2004) 'A study on charcoal supply in Kampala: Final report. Kampala, Uganda: Ministry of e nergy and Mineral Development.'

Laxmi, V., Parikh, J., Karmakar, S. and Dabrase, P. (2003) 'Household energy, women's hardship and health impacts in rural Rajasthan, India: Need for sustainable energy solutions', Energy for Sustainable Development, 7(1), pp. 50-68. doi: 10.1016/s0973-0826(08)60348-8.

Loiselle, C. G. Profetto-McGrath,J., Polit, D.F, and Beck, C.T ( 2004) ‘ Canadian essentials of nursing research'. First Edition. New York: Lippincott, Williams \& Wilkins. Peer reviewed. 537p

Martin, W. J., Hollingsworth, J. W. and Ramanathan, V. (2013) 'Household air pollution from Cookstoves: Impacts on health and climate', Global Climate Change and Public Health, , pp. 237-255. doi: 10.1007/978-1-4614-8417-2_13.

Oparinde, A. (2010) Investigating the relationship between income, health and biomass consumption: A panel data analysis. Available at: http://mpra.ub.uni-muenchen.de/39305/ (Accessed: 5 December 2015).

Peavy, H. S., Rowe, D. R. and Tchobanoglous, G. (1985) Environmental engineering. International Edition edn. McGraw-Hill Science/Engineering/Math.

Poortinga, W., Steg, L. and Vlek, C. (2004) 'Values, environmental concern, and environmental behavior: A study into household energy use', Environment \& Behavior, 36(1), pp. 70-93. doi: 10.1177/0013916503251466.

Reddy, A. (2000) 'Energy and Social Issues', in World energy assessment: Energy and the challenge of sustainability. New York, NY: United Nations Development Programme,

Sjöberg, L. and Engelberg, E. (2005) 'Lifestyles, and risk perception consumer behavior', International Review of Sociology, 15(2), pp. 327-362. doi: 10.1080/03906700500159755.

Smith, K. (1993) 'Fuel combustion, air pollution exposure, and health: The situation in developing countries', Annual Review of Energy and the Environment, 18(1), pp. 529-566. doi: 10.1146/annurev.energy.18.1.529.

Swami, R. (2012) Advantages and disadvantages of Biogas | Govardhan Ecovillage | simple living high thinking. Available at: http:/ / ecovillage.org.in/ecopedia/alternate-energy/advantages-and-disadvantages-of-biogas (Accessed: 5 December 2015)

Van Raaij, W. F. and Verhallen, T. M. M. (1983) 'A behavioral model of residential energy use', Journal of Economic Psychology, 3(1), pp. 39-63. doi: 10.1016/0167-4870(83)90057-0.

Victoria State Government (2015) Wood fires and breathing problems -Department of Health and Human Services - RHPER - Health Protection - Environmental Health Unit. Available at: https://www.betterhealth.vic.gov.au/health/healthyliving/wood-firesand-breathing-problems (Accessed: 5 December 2015).

WHO (2014) Fuel for life: Household energy and health. Available at: http://www.who.int/indoorair/publications/fuelforlife/en/ (Accessed: 5 October 2015).

WHO (2015) Household air pollution and health. Available at: http://www.who.int/mediacentre/factsheets/fs292/en/ (Accessed: 5 October 2015).

WHO World health organization (2015) Household Air Pollution. Available at: http:/ /www.who.int/phe/health_topics/outdoorair/en/ (Accessed: 5 December 2015).

World Health Organization, W. (2008) Children's Health and the Environment. Available at: http://www.who.int/ceh/capacity/Indoor_Air_Pollution.pdf (Accessed: 5 December 2015). 
